\title{
An assessment on provision of recreational facilities in Nigerian Universities in the $21^{\text {st }}$ century
}

\author{
Dr. S. B. C. Theanacho \\ Department of Human Kinetics \& Health Education \\ University of Calabar \\ Email: drsbciheanacho@yahoo.com \\ Dr. E. E. Ikpeme \\ Department of Human Kinetics \& Health Education \\ University of Calabar
}

Mr. I. A. Saba

Federal College of Education, Yola

Received: January 13, 2013 Accepted: February 28, 2013 DOI: 10.5296/jpag.v3i1.3380

\begin{abstract}
This paper is an assessment of provision recreational sports facilities in Nigerian Universities in the $21^{\text {st }}$ Century. The researcher having seen that adequate sports facility is an essential element in the effective delivery of sports program in Nigerian Universities, assessed some basic facilities in the first generation and some second generation Universities respectively. The data revealed that Nigerian Universities do not have sporting facilities befitting their status especially the second generation Universities. The paper went further to present some basic considerations for the provision of recreational sport facilities in Nigerian Universities. The role of Universities in the provision of recreational facilities was equally discussed in the paper. Finally, the paper recommends among others that Federal Government should declare a state of emergency on sporting facilities in Nigerian Universities because of the commonality in the problem of inadequacy and unavailability of standard recreational sports facilities in virtually all the Universities in Nigeria.
\end{abstract}

Keywords: Recreational facilities, Nigerian universities, education 


\section{Introduction}

In recent years, Nigerian University education, have witnessed increased population, rising University enrolment, and thus material costs of running the system have affected the provision of the needed facilities for sports in Universities. Be it as it may, plan for University usually encapsulate the provision of recreational sport facilities because sports is an integral part of the total learning package offered by the Universities, the world over. The provision and maintenance of sport infrastructure then becomes a necessary ingredence if the academic and recreational program of the University will attain its set goals. As Awosika (1982) observed, the availability, adequacy and maintenance of facilities and equipment are necessary conditions for running a good and meaningful program in sports and related fields.

Unavailability of sporting facilities is an impediment to the development of recreational sports in Nigeria Universities. This affects participation in sports by students and staff in the universities. The National Policy on Education (1989), while commenting stipulated that participation in sport should be the exclusive right of the citizens to ensure mass participation, moral, physical and mental growth of the people; it also encouraged decentralization of sport and the development of agencies to ensure mass participation to the grassroots as an economic tool and also for combating anti-social behavior.

Assessing the Nigerian Universities from the point of the provision of adequate facilities for students and staff recreational programs vis-a-vis raising high level athletes for the nation, one would realize that Universities in Nigeria have not made much impact on the nation's sports in this regards - despite the expectation placed on them to fulfill this role. Ojeme (2009), while commenting on the state of sports facilities in Nigerian Universities, stressed that, sports facilities in Nigerian Universities are rickety, perhaps with the very insignificant exception of Ahmadu Bello University, University of Port Harcourt, University of Lagos and University of Benin. The University budget in a year cannot even lift a single sport to a meaningful level and when applied to the multi-NUGA sports programs it amounts to nothing added. He further opined that the Nigerian University system is a lame duck, unable to make any significant impact in the nation's quest for sports excellence. Contributing further on the place of the provision and maintenance of sport facilities for effective sports programme delivery, Mgbor and Anyanjor, (2005); and Ojeme, (2005), all emphasized on the relevance of the presence, adequacy, supply and maintenance of equipment and facilities to the smooth operations of any sports and fitness programs.

From the above scenario, it may not be out of place for anyone to postulate that there may be impediments towards the realization of this thrust placed on Nigerian Universities. This paper therefore is an attempt to assess Nigerian Universities vis-à-vis the provisions of recreational sports facilities for students, staff and community recreational programs with a view to proffering suitable solutions.

\section{Rationale for Recreation Facilities in Nigerian Universities}

Universities the world over are centres of excellence in all fields of human learning and development. The University as an institution according to Ojeme (2009), is designed to 
provide a forum for young people to acquire knowledge and prepare for a productive life. He further stated that right from inception, sports has been part of University programs in Nigeria. However, the growing population of students in Nigerian University campuses resulting from enrolment for Remedial or Pre-degree and regular admissions into the Universities indeed, serve as a propelling force that engender the dare need for adequate provision of recreational facilities for high level sport service delivery to the students, staff and for community recreation.

\section{Sports and Recreational Facilities in Nigeria Universities}

A detailed investigation into the existing sports and recreational facilities in some selected Nigerian Universities (First and Second generation) in tables one and two, indicates a low level availability of the needed sports infrastructures such as stadia pitches, courts and indoor sports hall swimming pool, gymnastic to cater for the yearning of ever growing population of sports men and women and for community recreation in the 93 Universities nationwide; comprising 27 Federal, 32 state and 34 private Universities, (NUC, 2008). Also, not only that the sports facilities on Nigeria University campuses are grossly inadequate; the existing ones are substandard. The pride of Nigerian Universities today in terms of sporting facilities are the first generation Universities that have developed to taste some reasonable sporting facilities and have hosted Nigeria University Games (NUGA) at one time or the other. Even then, proper maintenance of these recreational facilities, though inadequate is still a mirage due to lack of institutional supports. Similarly Mgbor and Obiyemi, (2001) stressed that it is surprising to note that in all the over thirty Universities in Nigeria, only a negligible number can boast of modern tartan tracks. Facilities for other sports are also grossly inadequate and sometimes non-existent. In fact, Mgbor, (1989), maintained that most Nigerian Universities have little or no sports facilities befitting the status of Universities. He further observed, and equally disturbing, is that even where sports facilities are provided; they are often in a poor state of maintenance. The maintenance culture is nonexistent in the Universities in Nigeria

Table 1: Recreation (Sports) Facilities in First Generation Universities (Selected Sports)

\begin{tabular}{|l|c|c|c|c|c|c|c|}
\hline $\begin{array}{c}\text { University } \\
\text { Location }\end{array}$ & $\begin{array}{c}\text { Track } \\
\mathbf{4 0 0 m}\end{array}$ & $\begin{array}{c}\text { Basket } \\
\text { ball } \\
\text { court }\end{array}$ & $\begin{array}{c}\text { Indoor } \\
\text { Gymnastics }\end{array}$ & $\begin{array}{c}\text { Soccer } \\
\text { Pitch }\end{array}$ & $\begin{array}{c}\text { Swimming } \\
\text { Pool }\end{array}$ & $\begin{array}{c}\text { Tennis } \\
\text { Court }\end{array}$ & $\begin{array}{c}\text { Team } \\
\text { Handball } \\
\text { court }\end{array}$ \\
\hline 1. Ibadan & $1(\mathrm{Tt})$ & 4 & $1(\mathrm{NS}$ & 2 & 1 & 6 & 2 \\
\hline 2. Nsukka & $1(\mathrm{Tt})$ & 6 & 1 & 2 & 1 & 12 & 2 \\
\hline 3. Ife & $1(\mathrm{Tt})$ & 2 & 1 & 2 & 1 & 6 & 2 \\
\hline 4. Lagos & $1(\mathrm{Tt})$ & 2 & 1 & 1 & - & 4 & 2 \\
\hline 5. Zaria & $1(\mathrm{Tt})$ & 2 & 1 & 2 & 1 & 6 & 2 \\
\hline
\end{tabular}


$\mathrm{Tt}=$ Tartan

NS = Not Standard

Table 2: Recreational (Sport) Facilities in "Second Generation" Universities (Selected Sports)

\begin{tabular}{|l|l|l|l|l|l|l|l|}
\hline $\begin{array}{l}\text { University } \\
\text { Location }\end{array}$ & $\begin{array}{l}\text { Track } \\
\mathbf{4 0 0 m}\end{array}$ & $\begin{array}{l}\text { Basket } \\
\text { ball } \\
\text { Court }\end{array}$ & $\begin{array}{l}\text { Indoor } \\
\text { Gymnastics }\end{array}$ & $\begin{array}{l}\text { Soccer } \\
\text { Pitch }\end{array}$ & $\begin{array}{l}\text { Swimming } \\
\text { Pool }\end{array}$ & $\begin{array}{l}\text { Tennis } \\
\text { Court }\end{array}$ & $\begin{array}{l}\text { Team } \\
\text { Handball } \\
\text { Court }\end{array}$ \\
\hline 1. Buk & $1(\mathrm{Tt})$ & 2 & 1 & 2 & - & 2 & 1 \\
\hline 2. Calabar & $1(\mathrm{C})$ & 2 & $1(\mathrm{NS})$ & 2 & - & 2 & $1(\mathrm{NS})$ \\
\hline $\begin{array}{l}\text { 3. Port } \\
\text { Harcourt }\end{array}$ & $1(\mathrm{Tt})$ & 2 & 1 & 2 & 1 & 2 & 2 \\
\hline 4. Unillorin & $1(\mathrm{C})$ & 2 & 1 & 2 & - & 2 & 1 \\
\hline 5. Unimaid & $1(\mathrm{C})$ & 2 & $1(\mathrm{NS})$ & 2 & - & 2 & 1 \\
\hline
\end{tabular}

In table 2 above, it is quite clear that most of the facilities in these Universities are grossly inadequate and substandard except for University of Port Harcourt which hosted NUGA in 2004. University of Nigeria Nsukka in Table 1 achieved a whole lot due to hosting of NUGA in 2008. The second generation Universities are in dare need of standard recreational facilities to be able to venture into attempting to host the Nigerian University Games (NUGA).

\section{Basic Considerations in Provision of Recreational Sports Facilities}

Recognizing the vital role of equipment and facilities in the successful implementation of any sports program, Igbanugo (1999), as cited in Eleso, (2005) outlined some guidelines and principles for planning for facilities in order to ensure that those needs that informed the decision and plan for facilities are properly addressed. These guidelines and principles as outlined by Igbanugo (1999) are as follows:

1) Professionals in various sports as well as other specialized personnel must be involved in the planning and administration of these facilities.

2) Technical information can be procured in the form of standards and guide from various sources such as professional literatures and manuals.

3) Facilities should be planned with an eye to the future to prevent what happens often when facilities constructed become too small due to the increase in the number of people using the facilities.

4) Only Proven professionals should be employed in planning, building, administering and 


\section{Macrothink}

maintaining facilities.

In addition, while giving considerations to the provision of facilities and equipment for fitness programme, the following factors have been deemed apt;

1. Number of clients to be served;

2. Types of clients to be served;

3. Amount and kinds of equipment needed;

4. Number and qualification of staff, and

5. Projected growth of the programme (Ray, 1994; Grantham, Patton, York \& Winick, 1998).

Making these factors paramount when planning for recreational facilities and equipment for a fitness programme will not only spell success for the program, but will also help to ensure the adequate management of available resources while creating avenues for safeguards against unforeseen events (Elias and Solomon, 2010).

\section{Universities Role in the Provision of Recreational Facilities on Campuses}

The provision of recreation facilities for all sports programs in a University is indeed an affair that calls for huge dose of funds for the exercise. This funding implication for the provision of sporting infrastructures on our campuses should be reflected in the annual budget for each University every year which must be heavily supported by all stakeholders in the education industry in order for the Universities to be able to provide to needed/befitting sporting infrastructures on Nigerian University campuses.

Universities should scout for sport sponsorship from companies for sports infrastructural development and, also bid to host the bi-annual Nigerian University Staff Games Association (NUSSA) which has one of its cardinal objectives of helping Universities to own by constructing new sporting facilities and updating the existing ones. Each University should adopt high level maintenance culture by ensuring that every facility constructed should have plans for its maintenance to provide for their longevity.

\section{Conclusion}

The provision of Recreational sporting facilities in Nigerian Universities in the $21^{\text {st }}$ century will indeed contribute significantly to quality teaching, research and capacity building in sports which are quite critical to sports development in Nigerian Universities and the nation at large. No doubt, sports development infrastructure and proper maintenance of the facilities are very expensive ventures which must be tackled headlong if Nigerians Universities must be seen to fulfill the role of providing leadership in producing athletes for the nation's sports industry, and providing befitting sports facilities for the recreational program of University students, staff and for the community where the University is located. 


\section{$\Lambda$ Macrothink}

\section{Recommendations}

This paper recommends thus;

1. Government should increase her intervention funds to Universities to enable them meet up the development of sporting infrastructures.

2. Education Tax Funds (ETF) should earmark reasonable percentage of her annual fund generated to the development of sports facilities in Nigerian Universities.

3. Nigeria University Commission (NUC) should mandatorily request all Universities to take up sport development agenda as a priority program and ensure its implementation.

4. University's should have a standard indoor hall for badminton, table tennis and judo games.

5. Every University should have at least two pitches/counts for Basketball, Volleyball, Hockey Tennis, Badminton standard Table Tennis Tables.

6. Federal Government should declare a state of emergency on sport facilities in Nigerian Universities because of the problem of inadequacy and unavailability of standard recreation sports facilities in virtually all the Universities in Nigeria.

\section{References}

Awosika, B. Y. (1982). Intramural Programe in Some Selected Nigeria Universities. Unpublished Doctoral Thesis, University of Ibadan, Ibadan.

Elias, O. A. and Solomon, O. (2010). Adequacy and Functionality of Fitness Equipment and Facilities in Selected Fitness Centres in Edo and Delta States of Nigeria. Ozenu Journal of Applied Sciences 3(3).

Elso, T. (2005). Ensuring the Availability of Sporting Facilities and Equipment for the Success of the Universal Basic Education Program: Issues and Challenges. Journal of Nigerian Association for Physical, Health Education, Recreation Sport, and Dance. 2(1).

Grantham, Patton, York and Winick, (1998). Health Fitness Management. USA: Human Kinetics.

Mgbor, M. O. (1989). The Perceived Adequacy of Inputs Essential for Successful Implementation of Sports programs in Nigerian Universities. A Doctoral Dissertation, University of Benin.

Mgbor, M. O. and Anyanjo, A. (2005) The Development of School Sports in the Universal Basic Education Program: Challenges and Implications. Journal of Nigerian Association for Physical, Health Education, Recreation, Sports and Dance, 2(1).

Mgbor, M. O. and Obiyemi, W. O. (2001). Sports in Nigerian Universities: Present Status and Influencing Factors. Journal of Health, Physical Education, Sports and Leisure Studies. Vol.2, No.1, ABU - Zaria - Nigeria.

National University Commission, (2008). National Conference on Sports Development in Nigerian Universities: Abuja.

Ojeme, E. O. (2005). Towards the Effective Implementation of the Physical Education and Sports Curriculum in the Universal Basic Education Program. Journal of Nigerian 


\section{Macrothink \\ Journal of Public Administration and Governance ISSN 2161-7104 \\ 2013, Vol. 3, No. 1}

Association for Physical, Health Education, Recreation, Sports and Dance. 2(1).

Ojeme, E. O. (2009). New Challenges for Universities in Nigerian Sport.

Ray, R. (1994). Management Strategies in Athletic Training, USA: Human Kinetics. 